\title{
Performance Experimental Study of Solar Still With Reflector To Produce Fresh Water and Salt
}

\author{
Mulyanef ${ }^{1 *}$, Duskiardi $^{2}$, Kamaruzzaman Sopian $^{3}$, Kaidir $^{4}$, and Zulfika Rahman ${ }^{5}$ \\ 1,2,4,5 Department of Mechanical Engineering, University of Bung Hatta, 25143 Padang, Indonesia \\ ${ }^{3}$ Solar Energy Research Institute, Universiti Kebangsaan Malaysia, 43600 Bangi, Selangor, Malaysia
}

\begin{abstract}
This paper presents a study of experimental performance of solar still using reflector to produce fresh and salt water in the climate of Padang city, Indonesia. The solar collector is equipped with a reflector placed on the top of the cover with slope of $30^{\circ}$. Test results show that using reflector can increase temperature in the basin. Freshwater productivity also increases and speeds up time in producing salt. Average daily freshwater productivity increased by $16.8 \%$ during the testing period by adding reflector compared to solar still without reflector
\end{abstract}

\section{Introduction}

Solar energy is alternative energy that never runs out, clean and available almost all over the world. Indonesia is a maritime country, which has vast seas and the longest beaches in the world. People who live along the coast and small islands still have difficulty in getting fresh water for their daily needs. This problem can be solved by using simple solar still to process sea water into fresh water. Solar still is an environmentally friendly sea water treatment process and a great technology for wider use. Solar still can also be used to process sea water into salt by heating sea water continuously to dry. There are several ways to improve the performance of solar still, one of which is by adding a reflector to the side of the collector to increase solar radiation into basin liner. Figure 1 shows the simplest device of solar still. Basin has the depth of salt water and has transparent cover of solar radiation, which can block the wavelength radiation emitted by interior surface of collector. Slanting cover is placed for condensing water vapor and flow along the slope into condensate pool. The basin consists of black absorbent plate to maximize absorption of solar radiation, and is isolated on the outer surface to minimize heat loss. Several experimental and theoretical studies have been found in literature that examines the effects of using reflectors to improve performance of solar still. Al-Hayek and Badran [1] found that single-slope solar still with internal reflector was more productive (20\%) than solar still double-slope without reflector. Abdallah et al. [2] Experimental results show the thermal performance of traditional single-slope type of solar still can be improved by installing internal reflection mirror. Average freshwater productivity increases by $30 \%$ compared to the type of solar still without reflection mirror(reflector). Badran and Al-Tahaineh [3] have found the coupling effect of flat plate solar collector with solar still can increase freshwater productivity by $36 \%$. The deeper the

*Corresponding author: mulyanef@bunghatta.ac.id 
water inbasin, the less solar still productivity. Productivity of solar still is found proportional to the intensity of solar radiation.

Mulyanef et al. [4] analyzed the performance of solar still to process sea water into fresh water and salt. Using a flat plate collector with area of $140 \mathrm{~cm} \times 220 \mathrm{~cm}$ and sea water volume of $12,000 \mathrm{ml}$ in basin,we obtained $10.076 \mathrm{ml}$ of fresh water and 322 grams of salt. Tanaka and Nakatake [5] analyzed the effect of external reflector inclination angle of basin-type of solar still. Productivity of fresh water from solar still can be increased by inclining external reflector $30^{\circ}$ in summer. Tanaka [6] conducted a research on solar still using reflector placed at the bottom of flat plate collector. The amount of fresh water produced is increase throughout the year using flat plate base reflector.Khalifa and Ibrahim [7] reported the results of experimental investigations on basin productivity, solar still type with internal and external reflectors tilted at an angle of $0^{\circ}$ (vertical), $10^{\circ}, 20^{\circ}$ and $30^{\circ}$. Daily productivity is found to be greater for solar still with larger closing angle. The benefit of vertical external reflectors in winter is found decrease at cover angle exceeding $40^{\circ}$. The most productive solar still in winter is solar still with $20^{\circ}$ cover angle, and internal and external reflector tilt angle at $20^{\circ}$. Tanaka and Nakatake [8] concluded that increasing solar radiation absorbed by basin liner would increase daily output of solar still using internal and external reflectors. Furthermore, an increase in daily output above average throughout the year by adding an internal reflector was $22 \%$, which increased to $48 \%$ when both reflectors were used at glass cover slope angle of $20^{\circ}$. A.J.N. Khalifa [9] conducted research on the effects of internal and external reflectors on the performance of basin-type solar stills in various seasons. Daily productivity increased by $35.5 \%$ by adding internal and external reflectors. While using internal reflector only increase productivity by $19.9 \%$. Z.M. Omara et.al [10] studied the performance of the stepped solar still using internal and external reflectors. The result shows an increase in temperature on absorbent plate, ambient temperature, water temperature in basin, cover glass temperature compared to solar still without reflector.

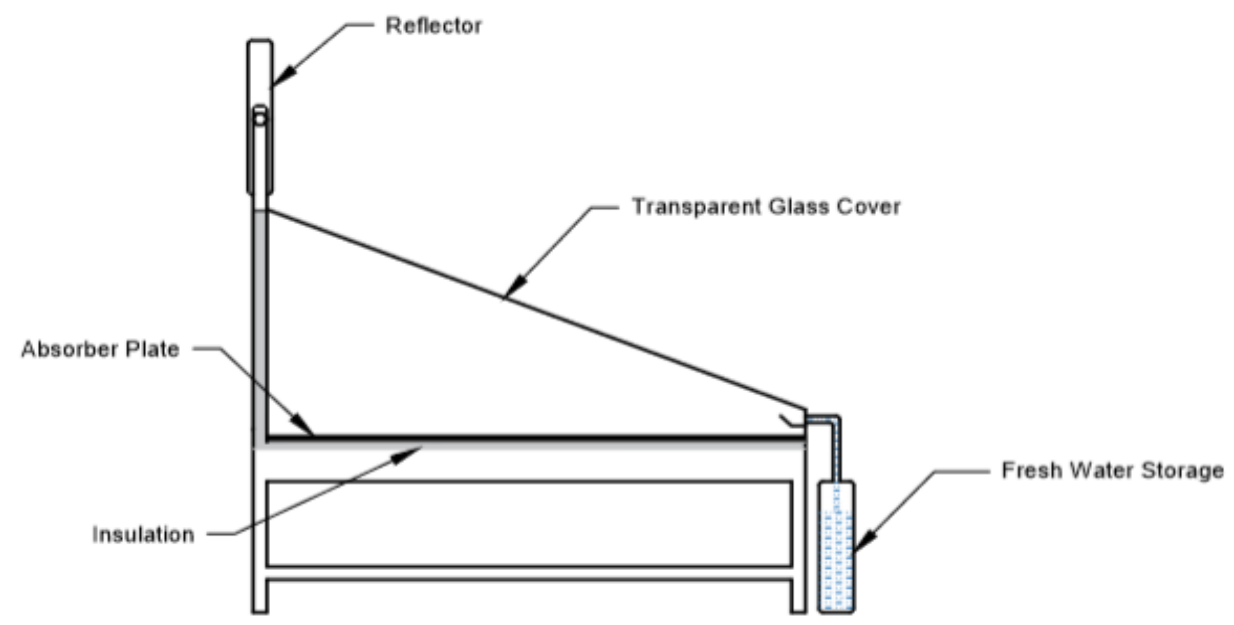

Fig.1. Schematic diagram of the solar still to produce fresh water and salt

\section{The experimental setup}

Solar still uses flat plate collector, which consists of absorbent plate, cover, insulation, reflector and freshwater reservoir. Absorbent plate with area of $1.96 \mathrm{~m} 2$, made of aluminum sheet and given black paint. The bottom and side of the collector are installed with glass wool insulation with a thickness of $2 \mathrm{~cm}$, and in other parts covered by galvanized sheets. At the 
top of the cover is a reflector with a size of $180 \mathrm{~cm} \mathrm{x} 42 \mathrm{~cm}$. The flat plate collector has a cover with tilt angle of $30^{\circ}$ made of glass. To drain condensate (fresh water) produced, at the bottom of the cover is placed condensate collection channel. Condensate channels are connected with plastic pipes to storage. Logger datais used to record the absorbent plate temperature, water temperaturein basin, evaporation temperature, outer glass cover temperature, ambient temperature, wind speed and solar intensity. Data is recorded every one hour from 9:00 am to 6:00 pm Padang time, Indonesia. To produce salt, the test is carried out continuously until sea water in the basin dries and salt is harvested. Seawater is reinserted into the basin for subsequent testing and fresh water (condensate) and salt are produced.

\section{Results and discussion}

Figure 2 shows different temperature variations of solar still with reflectors in the experiment conducted on April 17, 2017. It can be seen that the temperature of absorbent plate is the highest and is followed by evaporation temperature, water temperature in basin, glass temperature, and ambient temperature. The graph shows temperature relationship with time, when the temperature from 08.00 to 13.00 rises and then decreases until 17.00. The temperature of solar still collector with reflector is closely related to solar intensity. The higher the solar intensity, the higher the temperature in collector. This result is similar to the findings of many studies [1], [2], [3], [4].

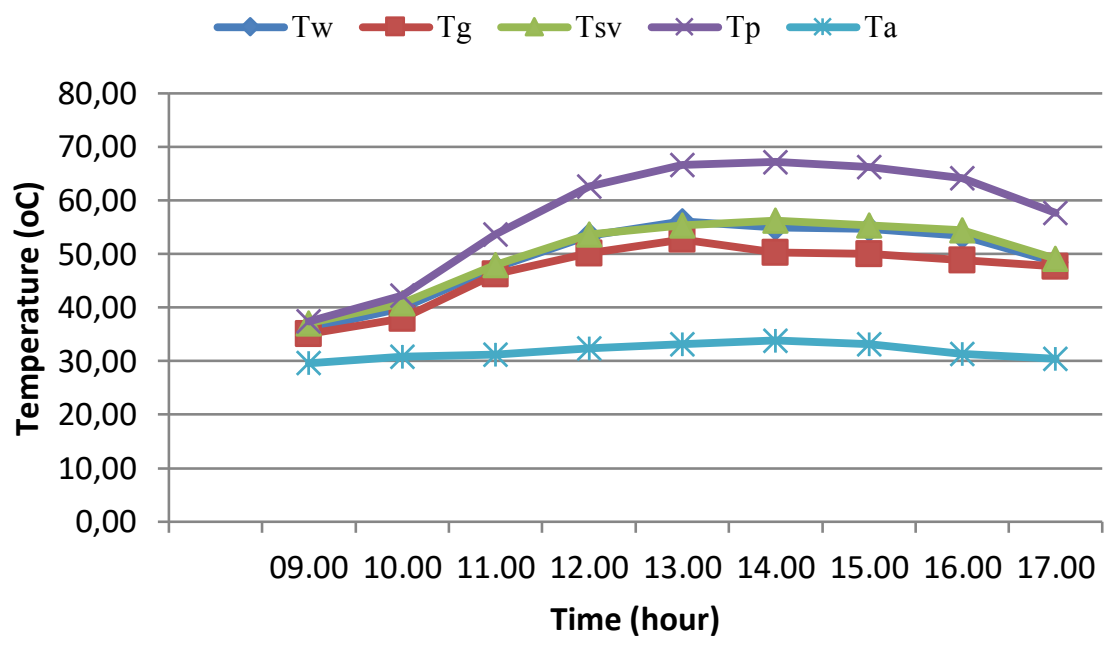

Fig 2. Different temperature variations on solar still with reflector 


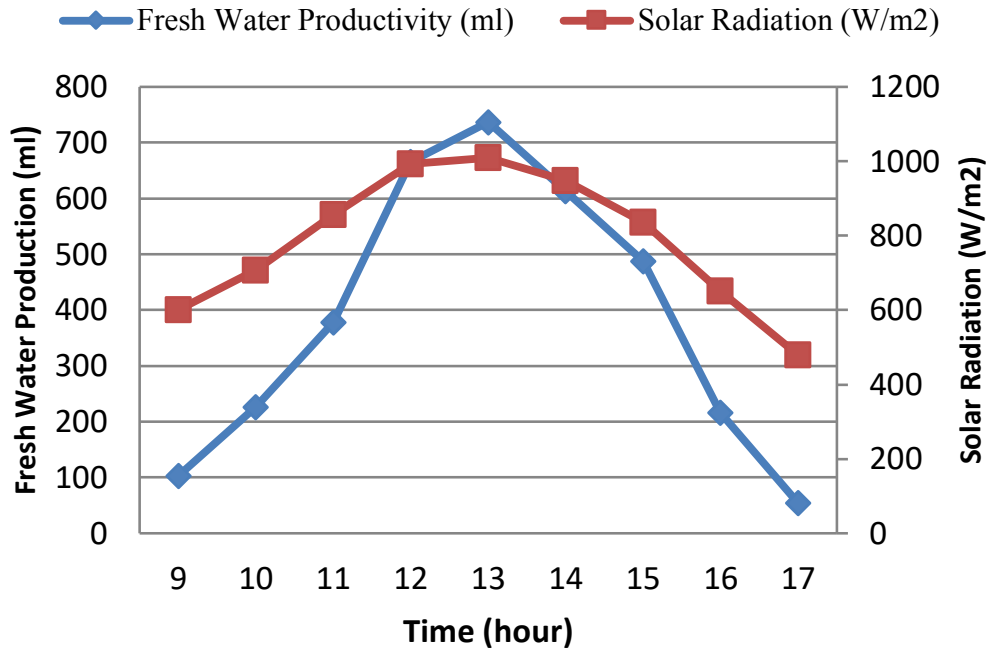

Fig 3. Relationship among freshwater productivity, time, and solar intensity

Figure 3. Showing the relationship among freshwater productivity, time and solar intensity in first test using reflectors (April 17, 2017). At 09.00, fresh water production had begun and continued to rise until 12:30 and after that the productivity of fresh water decreased to 17.00. In the graph, the productivity of fresh water is closely related to solar intensity. The higher the solar intensity the higher the productivity of fresh water produced. From 12 liters of sea water which was put into the collector's basin, $10.944 \mathrm{ml}$ of fresh water and 371 grams of salt were obtained. Test time required is 4 days to produce salt with average solar intensity of 696 $\mathrm{W} / \mathrm{m}^{2}$.

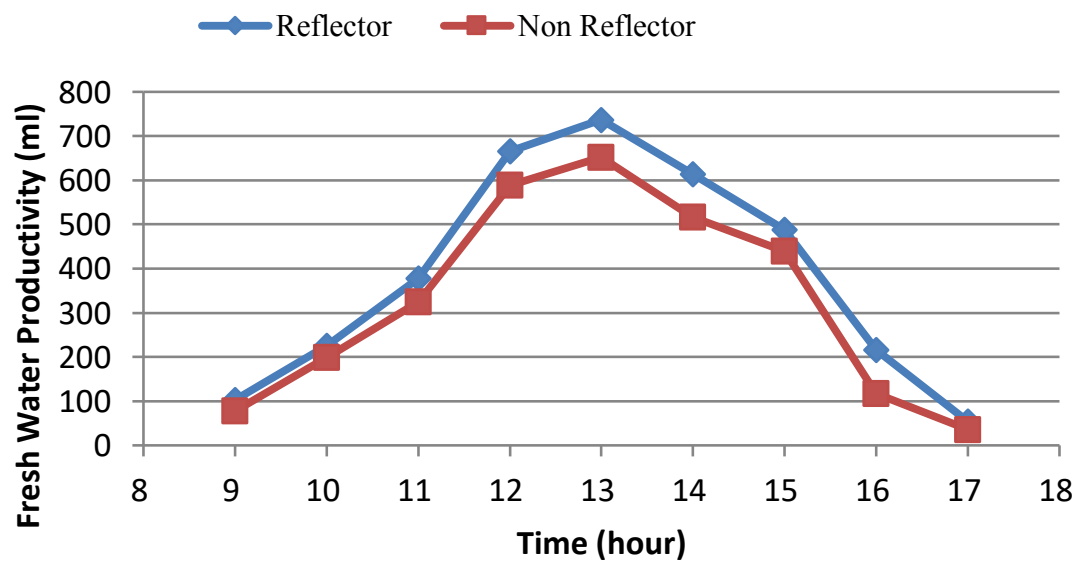

Fig 4. Comparison of freshwater productivity with time for solar still with reflector and non-reflector

Figure 4 shows a comparison of fresh water productivity for solar still using reflector and non-reflector. Freshwater productivity using reflector is higher than the type of non-reflector. Fresh water productivity is very dependent on solar intensity. The higher the solar energy, the more fresh water produced. The effect of solar radiation on condensate productivity is 
shown in Figure 4. For solar still using reflector with 12 liters of sea water and average solar intensity of $787 \mathrm{~W} / \mathrm{m} 2$, the amount of fresh water (condensate) on the first day was $3440 \mathrm{ml}$ / day. While the solar still without reflector produces $2945 \mathrm{ml}$ / day of fresh water. Reflectors on solar still have significant effect on increasing freshwater productivity $(18.6 \%)$, which is associated with the concentration of solar radiation reflected into the basin. H. Tanaka and Y. Nakatake [8] and A.J.N. Khalifa et.al [9] found the same results, that reflector is very influential in increasing productivity of solar still.

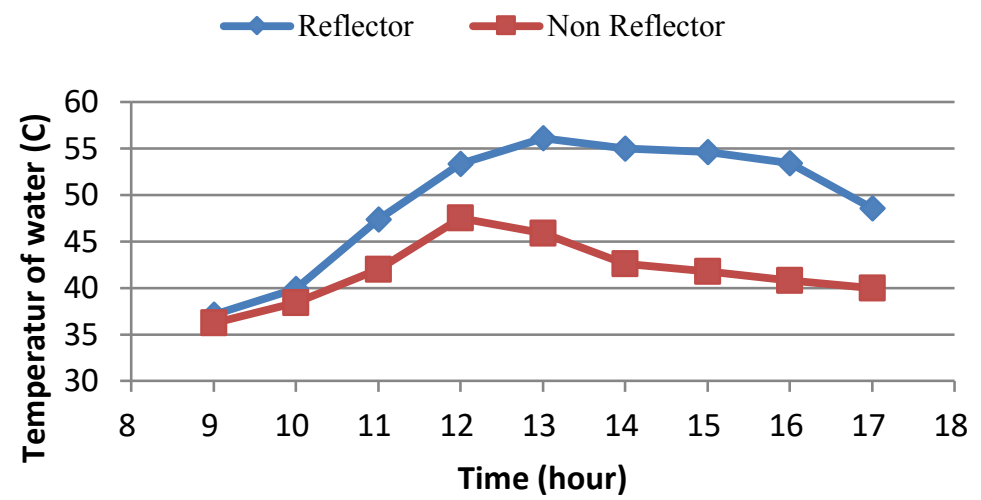

Fig 5. Relationship between water temperature in basin and time

Picture 5 displays relationship between water temperature in basin and time for solar still using reflector and non-reflector. High temperature for both solar still sizes is produced at 1:00 p.m. compared to $09.00-12.00$ and $14.00-17.00$. This is because solar intensity in the morning is still low, with time elapsed, intensity gets higher and after passing 12.0013.00 solar intensity drops again. For solar still using reflector, water temperature in basin is higher compared to non-reflector. The results of this test are the same as those conducted by Z.M. Omara et.al [10], that the temperature of water in the basin is higher for solar still with reflector.

\section{Conclusion}

The experimental results that have been carried out can be summarized as follows:

- The use of reflectors in simple solar still basins can increase solar still productivity.

- Productivity of solar still using reflector above collector cover increased $16.8 \%$, compared to solar still without reflector.

- The use of reflector in solar still basin can increase temperature in basin and can accelerate the time to produce salt..

\section{References}

1. I. Al-Hayek and O. Badran, The effect of using different designs of solar stills on water distillation, Desalination J, 169 121-127. (2004)

2. S. Abdallah, O. Badran and M. Abu-Khader, Performance evaluation of a modifi ed design of a single slope solar still, Desalination J, 219 222-230. (2008)

3. O.O. Badran and H.A. Al-Tahainah, The effect of coupling $\mathrm{fl}$ at plate collector on the solar still productivity, Desalination J, 183 137-142. (2005) 
4. Mulyanef, Duskiardi and Hidayat Rahmad, Performance Analysis of Sea Water Solar Still To Produce Fresh Water and Salt, Matec Web of Conferences, Proc. 159, 02013 (2018)

5. H. Tanaka and Y. Nakatake, Effect of inclination of the external $\mathrm{fl}$ at plate refl ector of basin type still in winter, Solar Energy J, 81 1035-1042. (2007)

6. H. Tanaka, Optimum inclination of still and bottom reflector for tilted wick solar still with flat plate bottom reflector, Desalination and Water Treatment J, 51 6482-6489. (2013)

7. A.J.N. Khalifa, H.A. Ibrahim, Effect of inclination of the external reflector of simple solar still in winter: An experimental investigation for different cover angles, Desalination J, 264 129-133. (2010)

8. H. Tanaka and Y. Nakatake, Theoretical analysis of a basin type solar still with internal and external reflectors, Desalination J, 197 205-216. (2006)

9. A.J.N. Khalifa and A.M and Hamood, H.A Ibrahim, Experimental study on the effect of internal and external reflectors on the performance of basin type solar stills at various seasons, Desalination and Water Treatment J, 27 313-318. (2011)

10. Z.M. Omara, A.E. Kabeel, M.M. Younes. Enhancing xthestepped solar still performance using internal and external reflectors, Energy Conversion and Management J, 78 876-881 (2014) 